male slave recovered, but for a year afterwards he looked like a skeleton, and the surviving woman ascribed her safety to only having eaten one bulb."'

\title{
MISCELLANEOUS.
}

Notice of the Occurrence, on the Durham Coast, of Diphyllidia lineata. By Albany Hancock, Esq.

In the early part of last year, the Rev. G. C. Abbes brought to me a small mollusk which he had obtained from the boats at Whitburn. On examination, this creature proved to be Diphyllidia lineata, a most interesting addition to the marine fauna, not only of the district, but of England. It has occurred only once before in the British seas; in September 1849, a single specimen having been dredged off Shetland by Mr. Barlee. These two, the only British examples, are much smaller than those obtained in the Mediterranean, and are more attenuated in form. Thinking, therefore, that our specimen might possibly be a distinct species, I was induced to examine its internal structure; and Mr. Alder having kindly supplied individuals of the true $D$. lineata, a strict comparison was instituted, which has resulted in determining that the two forms are identical.-Trans. of Tyneside Naturalists' Field Club, vol. ii. p. 128.

\section{IRISH MOLLUSCA.}

\section{To the Editors of the Annals of Natural History.}

Windsor Lodge, Monkstown, co. Dublin, August 5, 1852.

Gentlemen,-The following Mollusca are the results of three days' dredging in Birterbuy Bay, co. Galway. The first day I was accompanied by my friend Dr. Battersby of Torquay, who being pressed for time had to return to Dublin sooner than he expected, leaving me to pursue the conchological research in that delightful locality.

July 21.-Gastrochana modiolina; the scarcer variety found in cases composed of broken shells, \&c.

Pandora 乞btusa.

Lyonsia norvegica.

Thracia pubescens; one valve.

Psammobia tellinella.

vespertina.

Cardium fasciatum.

renodosum.

Circe minima, of the most beauti-

эrg7 ful marking.

Lepton squamosum.

- Arca tetragona.

Modiola tulipa.

Lima Loscombii.

Dentalium Tarentinum.

Chiton Asellus; very large.

Trochus Montagui.

Odostomia eulimoides.

Mangelia gracilis; dead.

- purpurea; dead.

- striolata.

- septangularis.

Cylichna conulus.

cylindracea; dead.

truncata; dead.

July 22.-Some of the shellsfound on the 21 st, as also Thracia convexa; dead.

Thracia pubescens.

Solen pellucidus.

Cardium pygmaum.

Lucina spinifera.

- Rexuosa. 


\section{$2 \mathrm{BHL}$ Biodiversity Heritage Library}

Hancock, Albany. 1852. "Notice of the occurrence, on the Durham Coast, of Diphyllidia lineata." The Annals and magazine of natural history; zoology, botany, and geology 10, 237-237. https://doi.org/10.1080/03745485609495683.

View This Item Online: https://www.biodiversitylibrary.org/item/19400

DOI: https://doi.org/10.1080/03745485609495683

Permalink: https://www.biodiversitylibrary.org/partpdf/10707

\section{Holding Institution}

Natural History Museum Library, London

\section{Sponsored by}

Natural History Museum Library, London

\section{Copyright \& Reuse}

Copyright Status: Public domain. The BHL considers that this work is no longer under copyright protection.

This document was created from content at the Biodiversity Heritage Library, the world's largest open access digital library for biodiversity literature and archives. Visit BHL at https://www.biodiversitylibrary.org. 